\title{
La déconstruction/reconstruction des "soi" dans les techniques de réanimation
}

\section{Stefan Timmermans}

\section{(2) OpenEdition}

1 Journals

Édition électronique

URL : https://journals.openedition.org/tc/516

DOI : $10.4000 /$ tc. 516

ISSN : 1952-420X

Éditeur

Éditions de l'EHESS

\section{Édition imprimée}

Date de publication : 1 mars 1996

ISSN : 0248-6016

\section{Référence électronique}

Stefan Timmermans, "La déconstruction/reconstruction des "soi" dans les techniques de réanimation », Techniques \& Culture [En ligne], 25-26 | 1996, mis en ligne le 28 octobre 2005, consulté le 29 septembre 2022. URL : http://journals.openedition.org/tc/516 ; DOl : https://doi.org/10.4000/tc. 516

Ce document a été généré automatiquement le 29 septembre 2022.

Tous droits réservés 


\section{La déconstruction/reconstruction des "soi" dans les techniques de réanimation}

Stefan Timmermans 